Article

\title{
The Influence of a Nanopatterned Scaffold that Mimics Abnormal Renal Mesangial Matrix on Mesangial Cell Behavior
}

\author{
Chia-Jung Chang ${ }^{1,2}\left(\mathbb{D}\right.$, Rin Minei $^{3}$, Takeshi Sato ${ }^{3}$ and Akiyoshi Taniguchi ${ }^{1,2, *(1)}$ \\ 1 Department of Nanoscience and Nanoengineering, Graduate School of Advanced Science and Engineering, \\ Waseda University, 3-4-1 Okubo, Shinjuku-ku, Tokyo 169-8555, Japan; CHANG.Chiajung@nims.go.jp \\ 2 Cellular Functional Nanobiomaterials Group, Research Center for Functional Materials, National Institute \\ for Materials Science, 1-1 Namiki, Tsukuba, Ibaraki 305-0044, Japan \\ 3 Glycobiology Laboratory, Nagaoka University of Technology, 1603-1 Kamitomiokamachi, Nagaoka, \\ Niigata 940-2137, Japan; s163385@stn.nagaokaut.ac.jp (R.M.); taksato@vos.nagaokaut.ac.jp (T.S.) \\ * Correspondence: taniguchi.akiyoshi@nims.go.jp; Tel.: +81-29-860-4505
}

Received: 6 September 2019; Accepted: 26 October 2019; Published: 28 October 2019

check for updates

\begin{abstract}
The alteration of mesangial matrix (MM) components in mesangium, such as type IV collagen (COL4) and type I collagen (COL1), is commonly found in progressive glomerular disease. Mesangial cells (MCs) responding to altered MM, show critical changes in cell function. This suggests that the diseased MM structure could play an important role in MC behavior. To investigate how MC behavior is influenced by the diseased MM 3D nanostructure, we fabricated the titanium dioxide $\left(\mathrm{TiO}_{2}\right)$-based nanopatterns that mimic diseased MM nanostructures. Immortalized mouse MCs were used to assess the influence of disease-mimic nanopatterns on cell functions, and were compared with a normal-mimic nanopattern. The results showed that the disease-mimic nanopattern induced disease-like behavior, including increased proliferation, excessive production of abnormal MM components (COL1 and fibronectin) and decreased normal MM components (COL4 and laminin $\alpha 1$ ). In contrast, the normal-mimic nanopattern actually resulted in cells displaying normal proliferation and the production of normal MM components. In addition, increased expressions of $\alpha$-smooth muscle actin ( $\alpha$-SMA), transforming growth factor $\beta 1$ (TGF- $\beta 1$ ) and integrin $\alpha 5 \beta 1$ were detected in cells grown on the disease-mimic nanopattern. These results indicated that the disease-mimic nanopattern induced disease-like cell behavior. These findings will help further establish a disease model that mimics abnormal MM nanostructures and also to elucidate the molecular mechanisms underlying glomerular disease.
\end{abstract}

Keywords: mesangial matrix; type I collagen (COL1); type IV collagen (COL4); $\mathrm{TiO}_{2}$-based nanopattern

\section{Introduction}

Kidney disease due to acute kidney injury and/or chronic kidney diseases is frequent in different diseases and disorders, such as glomerulonephritis, inflammatory bowel diseases (IBD), diabetic nephropathy and renal fibrosis [1-3]. It is characterized by reduced kidney function, which includes the mesangial cell (MC) proliferation, glomerular and tubular damage with loss of glomerular filtration function and raised biomarkers, angiopoietins- 2 and neutrophil gelatinase-associated lipocalin (NGAL) [4-6]. These biomarkers can be diagnosed in the early stage of the kidney disease, and have the potential to prevent the progression toward end-stage renal disease [3]. 
Mesangium expansion, caused by aberrant mesangial cell proliferation, is a common histopathological abnormality widely found, not only in glomerular diseases, but also in IBD-associated renal disease [1,2].

Over-proliferation of MCs can lead to accumulation of excessive extracellular matrix (ECM) in the mesangial matrix (MM) $[7,8]$. The accumulated ECM then results in renal fibrosis, and finally leads to end-stage renal failure [9].

MCs are specialized cells of the renal glomerulus that embed in the MM that they secrete [1]. Normal MCs have an irregular stellate shape with numerous pseudopods extending into the MM, and are connected to the glomerular basement membrane in vivo [10]. Fusiform and elongated MCs indicate a high proliferative rate, whereas the stellate cells have a very humble growth response [11]. In addition, MCs form myofibroblasts and express alpha-smooth muscle actin ( $\alpha$-SMA), which are key in the process of MC activation during glomerular disease [12]. Hence, MCs are critical players in the initiation and progression of several glomerular diseases [1,13].

MCs are also responsible for generating and controlling MM turnover, which provides structural support for the glomerular capillary structure [14]. MM is a basement membrane-like structure that is predominantly composed of type IV collagen (COL4), laminin, fibronectin and heparan sulfate proteoglycan under normal conditions in vivo [11,14]. Within these ECM components, COL4 forms the major skeleton of MM $[15,16]$. In diseased conditions, interstitial matrix components, such as type I collagen (COL1) and fibronectin, have been reported to accumulate in MM, and they directly result in mesangium expansion and contribute to a variety of glomerular diseases. COL1 is the main interstitial ECM component, and does not appear in normal MM [2,11,17]. Our previous study indicated that altered collagen glomerular components, including an increase in COL1 and a decrease in COL4, are involved in an IBD animal model [2]. Other previous studies using in vitro flat 2D culture systems have demonstrated that MCs cultured on COL1 gels result in increased proliferation and increased expression of COL1, fibronectin and transforming growth factor beta 1 (TGF- $\beta 1$ ), compared to those cultured on COL4 gels [18-20], suggesting that abnormal MM components can alter cell functions. Since the components of MM play a critical role in maintaining MC morphology, the structure of MM is important to regulate MC behavior, even for renal function [15]. However, the influence of a diseased MM 3D nanostructure on MC behavior is not yet understood.

Native collagen fibers are arranged into a 3D structure and are around $300 \mathrm{~nm}$ to $1 \mu \mathrm{m}$ in diameter [21,22]. They are hierarchically structured from collagen fibrils in 40 to $100 \mathrm{~nm}$ diameters that are identifiable in the MM [23]. In addition, the renal basement membrane consists of a meshwork-forming structure with pores ranging from 4 to $50 \mathrm{~nm}$ [24]. The varying diameter of collagen fibers is correlated with health and disease conditions [25]. Thus, it is very important to investigate the cell behavior response to native nano-topologies. To address these issues, advanced nanofabrication techniques, such as electron beam lithography (EBL), offer novel tools to closely mimic the in vivo natural structure and to elucidate the mechanisms that influence cell responses to ECM by creating various nanopatterned topographical features [26-28]. Although the precise mechanism underlying the cell behavior as influenced by nano-topography is still unclear, it is possible that cells recognize the changed microenvironment by sensing the ECM nano-topography, triggering ECM remodeling [29]. Therefore, mimicking the abnormal nano-topography in diseased environments is critical to understanding how cells modulate their cellular function and activities to respond to pathological change.

In this study, nanopatterning to mimic the diseased MM nano-topography was performed on a titanium dioxide $\left(\mathrm{TiO}_{2}\right)$ substrate by EBL and atomic layer deposition (ALD), as previously reported [30]. We investigated the influence of disease-mimic nanopatterned topographies on MC behavior. We studied the influence of disease-mimic nanopatterns on MC functions, including proliferation and expressions of specific types of ECM component, and compared them with those of a normal-mimic nanopattern. We also investigated the possible mechanisms by which disease-mimic nano-topographical features influence MC behavior. Our results showed that the disease-mimic 
nanostructure guides MCs to display disease-like behavior. These findings are important for further establishing a disease model that mimics MM to study the molecular mechanisms of its pathogenesis, as well as to screen for and develop new drugs specific for patients with glomerular disease.

\section{Results}

\subsection{Design and Fabrication of Disease- and Normal-mimic Nanopatterned $\mathrm{TiO}_{2}$ Substrates}

In this study, we hypothesized that disease-mimic nano-topographical features would influence MC behavior by affecting cell morphology. To examine MC behavior influenced by disease-mimic nano-topographical features, three different fibril-forming nanopatterns were designed. In addition, one network-forming nanopattern and an unpatterned flat control were also used. Our nanopatterning was inspired by the fact that the diameters of collagen fibrils in natural $\mathrm{MM}$ are 40 to $100 \mathrm{~nm}$ [23]. However, due to the limitations of the ALD of samples on the patterns fabricated by EBL, approximately $80 \mathrm{~nm}$ was the minimum dimension. The dimensions and topographical variations of fabricated nanopatterns were characterized with scanning electron microscopy (SEM) and atomic force microscopy (AFM) (Figure 1). To optimize the disease-mimic nanopattern, three different nano-gratings of fibril-forming nanopatterns were used: $80 \mathrm{~nm}$ wide and $80 \mathrm{~nm}$ apart (F80/80, Figure 1A,F), $80 \mathrm{~nm}$ wide and $200 \mathrm{~nm}$ apart (F80/200, Figure 1B,G) and $200 \mathrm{~nm}$ wide and $80 \mathrm{~nm}$ apart (F200/80, Figure 1C,H), which mimic the collagen fibril and fibril spacing. The network-forming nanopattern, which mimics the normal MM nanostructure (normal-mimic), was $80 \mathrm{~nm}$ wide and $80 \mathrm{~nm}$ apart, with pores approximately $50 \mathrm{~nm}$ in diameter (Figure 1D,I). The unpatterned flat substrate (Figure 1E,J) presented a comparatively smooth surface. All the nanopatterns were $80 \mathrm{~nm}$ in height. SEM and AFM images showed that the dimensions of the ridge/groove-nanopatterns were highly uniform and well defined, without obvious defects. 

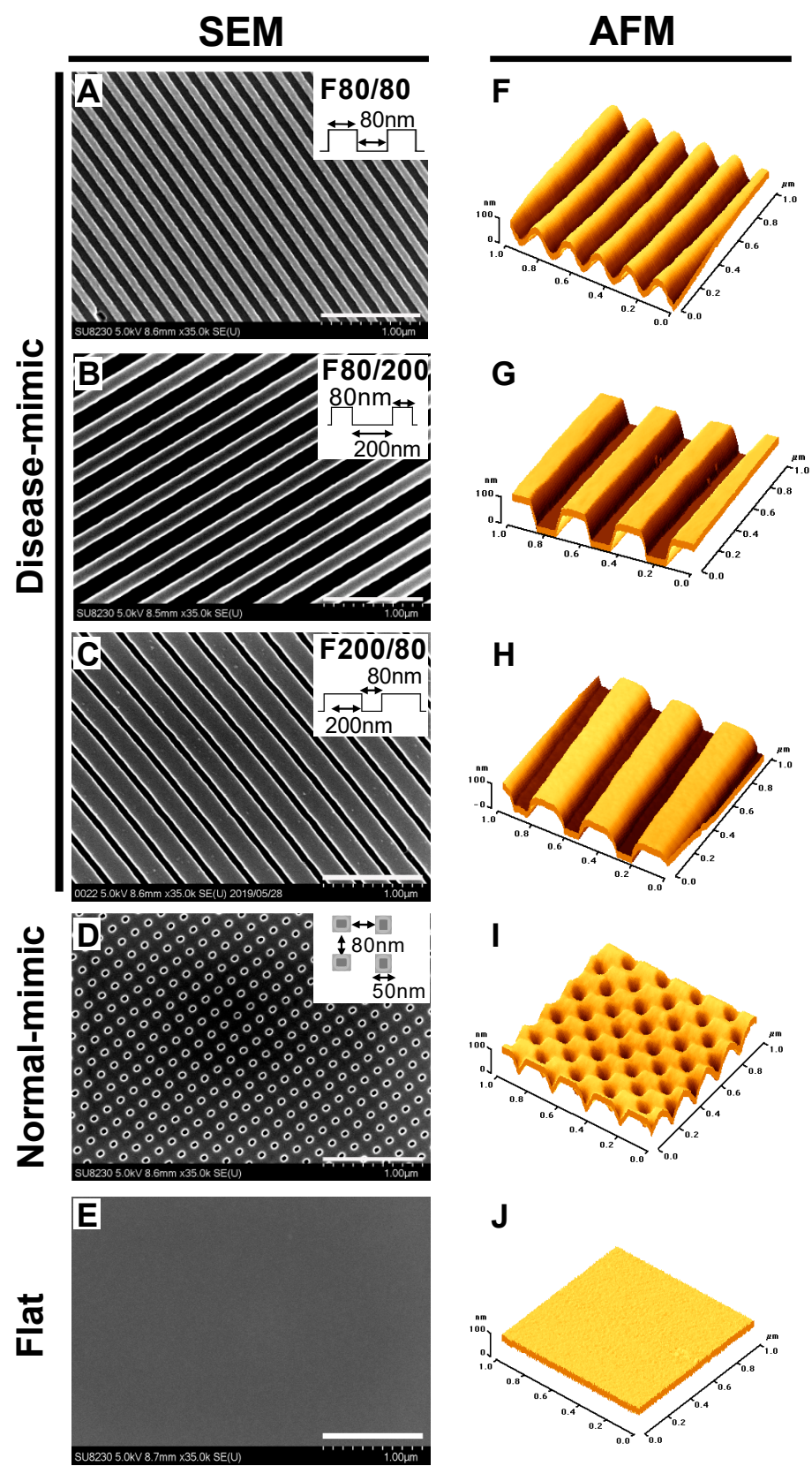

Figure 1. Images of fabricated titanium dioxide $\left(\mathrm{TiO}_{2}\right)$ nanopatterns. Scanning electron microscopy (SEM) was utilized to confirm the morphologies of three disease-mimic nanopatterns (A-C), a normal-mimic nanopattern, (D) and a flat control (E). Illustrations show the approximate dimensions of ridge/groove pattern arrays. The depth of gratings was $80 \mathrm{~nm}$. Scale bar $=1 \mu \mathrm{m}$. Atomic force microscopy (AFM) graphs show topographies of each $\mathrm{TiO}_{2}$ nanopattern $(\mathbf{F}-\mathbf{J})$.

\subsection{MES13 Cell Proliferation on Disease-Mimic Nanopatterns}

Aberrant MC proliferation in mesangium is commonly observed in patients with glomerular disease [31,32]. To screen for nano-topographical features that closely mimic diseased MM, 5-ethynyl-2'-deoxyuridine (EdU) proliferation assays were performed by counting the percentage of MES13 cells with incorporated EdU, which indicates newly-synthesized DNA (shown in green) after $24 \mathrm{~h}$ of seeding on F80/80 (Figure 2A-a), F80/200 (Figure 2A-b), F200/80 (Figure 2A-c), normal-mimic (Figure 2A-d) and flat control (Figure 2A-e). The results showed that a significant increase in cell proliferation was observed in cells cultured on disease-mimic nanopatterns, including F80/80, F80/200 
and F200/80. In addition, the proliferation of cells cultured on the F80/200 nanopattern was significantly higher than that of cells cultured on F80/80 and F200/80 nanopatterns.

In contrast, cells grown on the normal-mimic nanopattern showed cell proliferation as low as those on the flat control (Figure 2B). These results revealed that the disease-mimic nanopattern F80/200 dramatically enhanced MES13 cell proliferation.

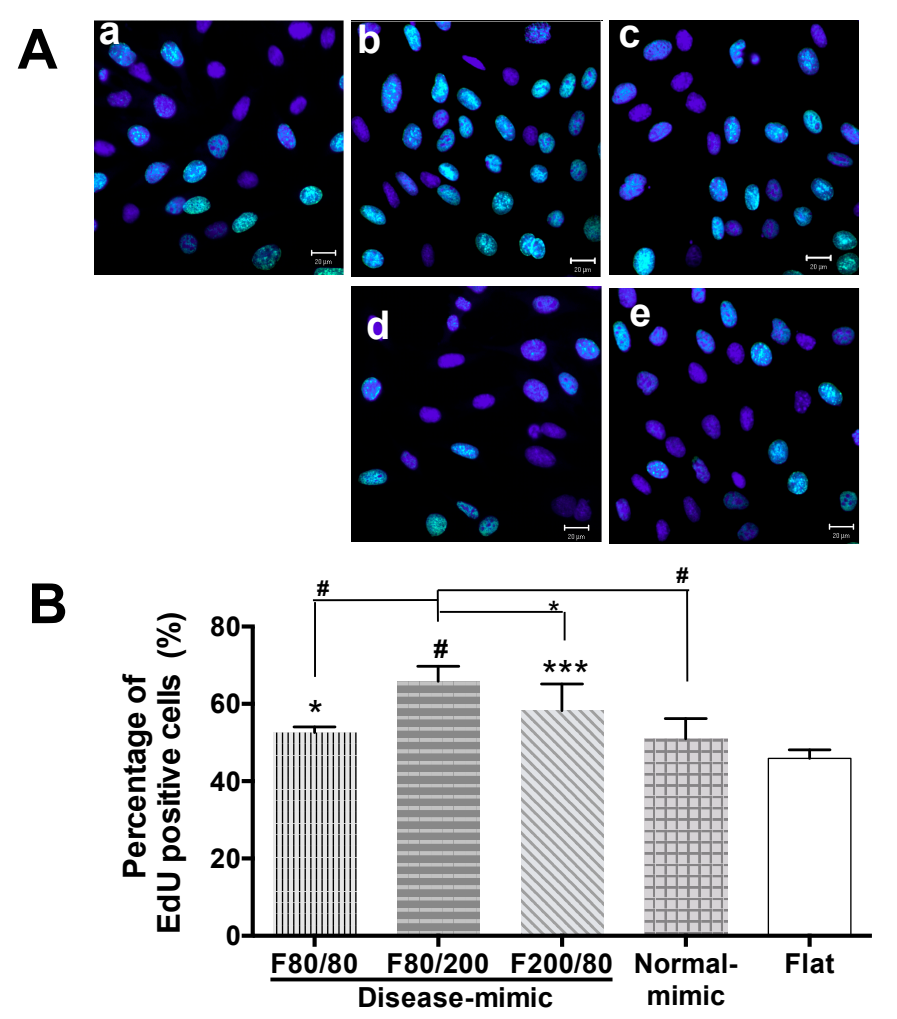

Figure 2. Proliferation of MES13 cells cultured on disease- and normal-mimic nanopatterns. (A) Cells were cultured on F80/80 (a), F80/200 (b), F200/80 (c), normal-mimic (d) and flat control (e) for 24 h, and then proliferation was determined by the 5-ethynyl-2'-deoxyuridine (EdU) assay. Fluorescence images show EdU incorporation into the nuclei of cells. EdU-positive cells are green, and nuclei stained with 4',6-diamidino-2-phenylindole (DAPI) are blue. (B) Percentage of EdU-positive cells. Data are reported as means \pm SEM for three independent experiments. Statistically significant at ${ }^{*} p<0.05,{ }^{* * *} p<0.0005$, and $^{\#} p<0.0001$ Analysis of Variance (ANOVA). Scale bar $=20 \mu \mathrm{m}$.

\subsection{Expressions of Specific ECM Components in MES13 Cells}

One critical role of mesangial cells is to synthesize MM to provide support to glomerular capillaries [1]. To examine the influence of disease-mimic nanopatterns on ECM component expression in MES13 cells, immunofluorescence staining was performed for COL4, laminin $\alpha 1$, COL1, and fibronectin after cells were grown on $\mathrm{TiO}_{2}$ nanopatterns for $48 \mathrm{~h}$. Decreased COL4 expression was detected in cells grown on F80/80, F80/200 and F200/80 nanopatterns, compared to those grown on the normal-mimic nanopattern and flat control (Figure 3A). Consistently, an obvious decrease in laminin $\alpha 1$ expression was observed in cells on F80/80, F80/200 and F200/80 nanopatterns (Figure 3B). In contrast, increased COL1 and fibronectin expressions were detected in cells on the F80/80, F200/80 and particularly the F80/200 nanopattern, when compared to the normal-mimic nanopattern and flat control (Figure 3C,D). These results indicated that MES13 cells expressed disease-like MM components when grown on the F80/200 fibril nanopattern, which is similar to diseased MCs. 

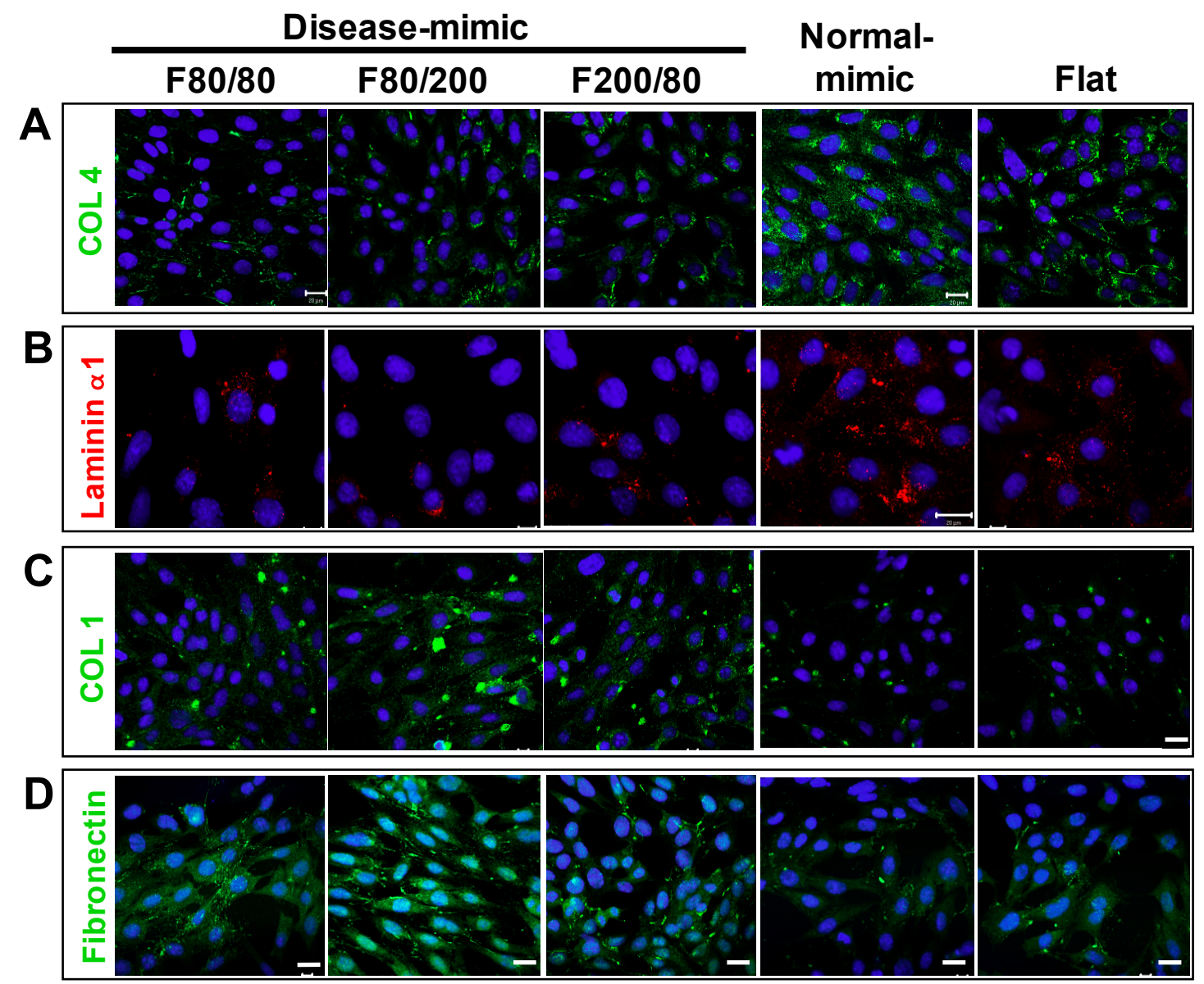

Figure 3. Expressions of extracellular matrix (ECM) components in MES13 cells cultured on diseaseand normal-mimic nanopatterns. Cells were cultured on various $\mathrm{TiO}_{2}$ nanopatterns for $48 \mathrm{~h}$ and immunostained for the following ECM components: Type IV collagen (A, COL4, green), laminin $\alpha 1$ (B, red), type I collagen (C, COL1, green) and fibronectin (D, green). The nuclei were stained with $4^{\prime}$,6-diamidino-2-phenylindole (DAPI) (blue), and the fluorescence images were taken with a confocal microscope. Scale bar $=20 \mu \mathrm{m}$.

\subsection{MES13 Cell Morphological and Cytoskeletal Changes}

The altered morphology of MCs may affect cell functions such as cell adhesion, proliferation and $\mathrm{MM}$ component secretion $[7,11,33]$. To investigate the influence of nano-topographical features on MES13 cell morphology and cytoskeletal changes after $24 \mathrm{~h}$ of seeding on $\mathrm{TiO}_{2}$ nanopatterns, a qualitative assessment of the morphology was performed using SEM, and results showed cell attachment and spreading on all nanopatterns. MES13 cells exhibited a fusiform and elongated morphology, which is characteristic of activated myofibroblasts, when grown on the F80/200 nanopattern (Figure 4B), revealing that cells orient along the direction of the nanopattern $80 \mathrm{~nm}$ wide and $200 \mathrm{~nm}$ apart. However, cells did display a multipolar and stellate morphology on the F80/80, F200/80, normal-mimic and flat control nanopatterns (Figure 4A,C-E). In immunofluorescent images, actin stress fibers and vinculin can be observed on MES13 cells growing on $\mathrm{TiO}_{2}$ nanopatterns. The staining of F-actin filaments by rhodamine-conjugated phalloidin revealed a cytoskeletal arrangement that corresponds to the cell morphology stretched along the long axis of the cells. Cells grown on the F80/200 nanopattern showed an elongated morphology consistent with SEM images, and were mostly parallel to one another (Figure 4G). In addition, fewer stress fibers were observed in cells grown on the flat control (Figure 4J) compared to the other nanopatterns Figure $4 \mathrm{~F}-\mathrm{I}$ ). The actin-binding protein vinculin has been reported to associate with the actin cytoskeleton via focal adhesion (FA) [34]. Vinculin immunostaining was performed to further characterize cell morphology during growth on various nanopatterns. The results 
showed that cells grown on the F80/80, F80/200 and F200/80 nanopatterns (Figure 4K-M) had diffused vinculin staining in the cytosol, whereas clear FA spots were distributed throughout the cell bodies. However, slightly diffused vinculin staining in the cytosol and smaller FA spots appeared in cells grown on the F80/200 nanopattern (Figure 4L). Less vinculin diffusion was detected in cells on the normal-mimic nanopattern, with clear FA spots distributed both at the cell periphery and throughout the cell bodies (Figure $4 \mathrm{~N}$ ). Cells grown on the flat control displayed diffused vinculin staining in the cytosol, and FA spots were distributed only at the cell periphery (Figure 4O). Diffused localization of vinculin is indicative of limited FA maturation in cells. These findings revealed that the F80/200 nanopattern reduced FA maturation, whereas the normal-mimic nanopattern promoted cells to form mature FAs. These findings indicated that the disease-mimic F80/200 nanopattern affected cellular morphology and focal adhesion.

\section{5. $\alpha$-SMA Expression in MES13 Cells}

$\alpha$-SMA has been identified as a marker of MC activation that is expressed during glomerular injury [12,35]. To determine whether the disease-mimic nanopatterns influenced MES13 cell activation, $\alpha$-SMA expression and localization were performed by immunofluorescence staining. The results showed that the cells had a higher expression of $\alpha$-SMA when grown on the F80/200 nanopattern than when grown on the other nanopatterns (Figure 5). In addition, $\alpha$-SMA is localized to the cytoplasm in cells grown on the F80/200 nanopattern. Large $\alpha$-SMA localization to the nuclei of cells grown on F200/80, the normal-mimic and the flat control nanopattern, revealed that the F80/200 nanopattern did induce the MES13 cell activation similarly to the diseased condition.

\subsection{TGF- $\beta 1$ Expression in MES13 Cells}

TGF- $\beta 1$ is a key mediator in the progression of renal fibrosis [36]. It has been demonstrated that TGF- $\beta 1$ stimulates $\alpha$-SMA expression in MCs during the progression of the disease $[37,38]$. Thus, to further examine whether TGF- $\beta 1$ is involved in the influence of the disease-mimic nanopattern on ECM components and $\alpha$-SMA expression, TGF- $\beta 1$ expression and localization were determined by immunofluorescence staining. As a result, higher TGF- $\beta 1$ expression was detected in the cell leading edge when grown on the F80/200 nanopattern compared to the other nanopatterns (Figure 6), revealing that the F80/200 nanopattern-induced ECM component and $\alpha$-SMA expression changes could be mediated by TGF- $\beta 1$.

\subsection{Integrin $\alpha 5 \beta 1$ Expression in MES13 Cells}

Integrin $\alpha 5 \beta 1$ is a crucial molecule in mediating human mesangial cell adhesion to fibronectin [39]. To assess the correlation of fibronectin matrix production in MES13 cells when grown on various nano-topographical scaffolds, the expression of integrin $\alpha 5 \beta 1$ was determined by immunofluorescence staining. The results showed an obvious expression of integrin $\alpha 5 \beta 1$ in cells grown on the F80/200 nanopattern compared to the other nanopatterns (Figure 7), revealing that F80/200-nanopatterned topography-induced fibronectin accumulation could be mediated by integrin $\alpha 5 \beta 1$. 

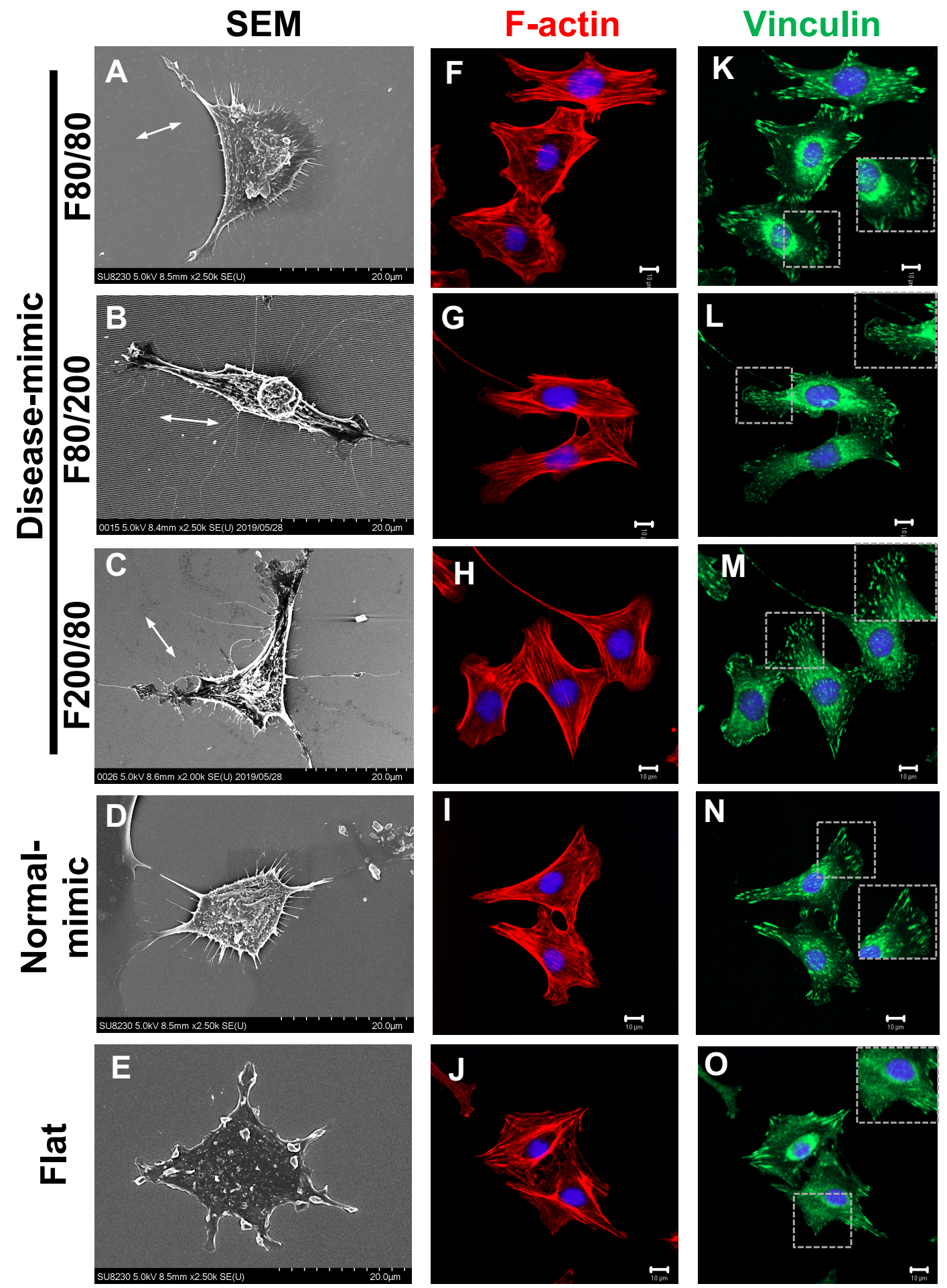

Figure 4. MES13 cell morphological and cytoskeletal changes in disease- and normal-mimic nanopatterns. Cells were adhered to various $\mathrm{TiO}_{2}$ nanopatterns for $24 \mathrm{~h}$, and cellular morphology was observed by SEM micrographs (A-E). Confocal microscopy images show the actin cytoskeleton (F-J, red), the cytoskeletal protein vinculin (K-O, green) and nuclei (blue) in cells after culturing on $\mathrm{TiO}_{2}$ nanopatterns for $24 \mathrm{~h}$. The inlay highlights the focal adhesion spots. Scale bar $=20 \mu \mathrm{m}(\mathbf{A}-\mathbf{E})$ or $10 \mu \mathrm{m}$ (F-O). The white arrow indicates the direction of the nano-gratings. 


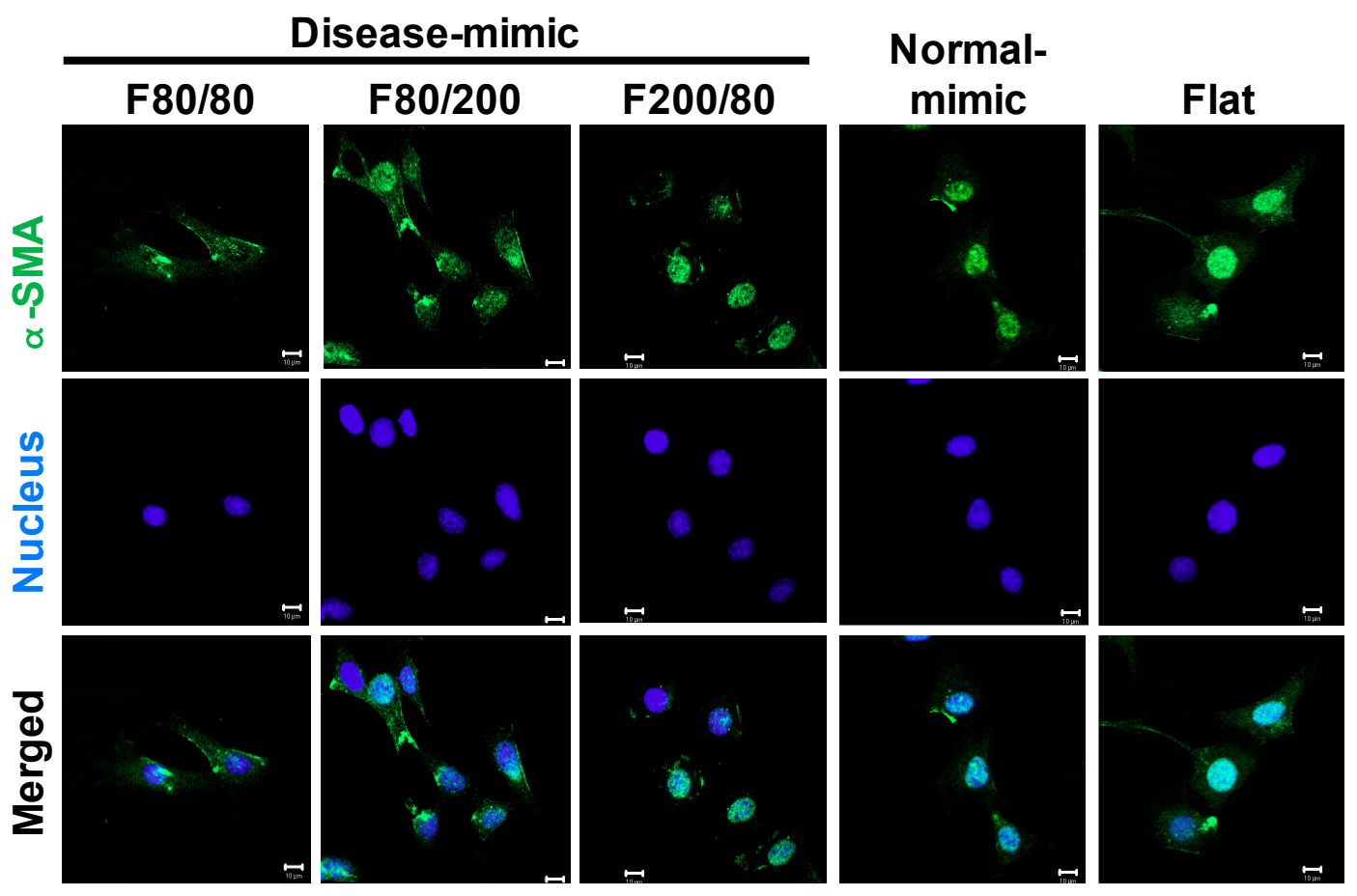

Figure 5. Alpha-smooth muscle actin ( $\alpha$-SMA) expression in MES13 cells influenced by disease- and normal-mimic nanopatterns. Confocal microscopy images show $\alpha$-SMA (green) and nuclei (blue) in cells after culturing on $\mathrm{TiO}_{2}$ nanopatterns for $24 \mathrm{~h}$. Scale bar $=10 \mu \mathrm{m}$.

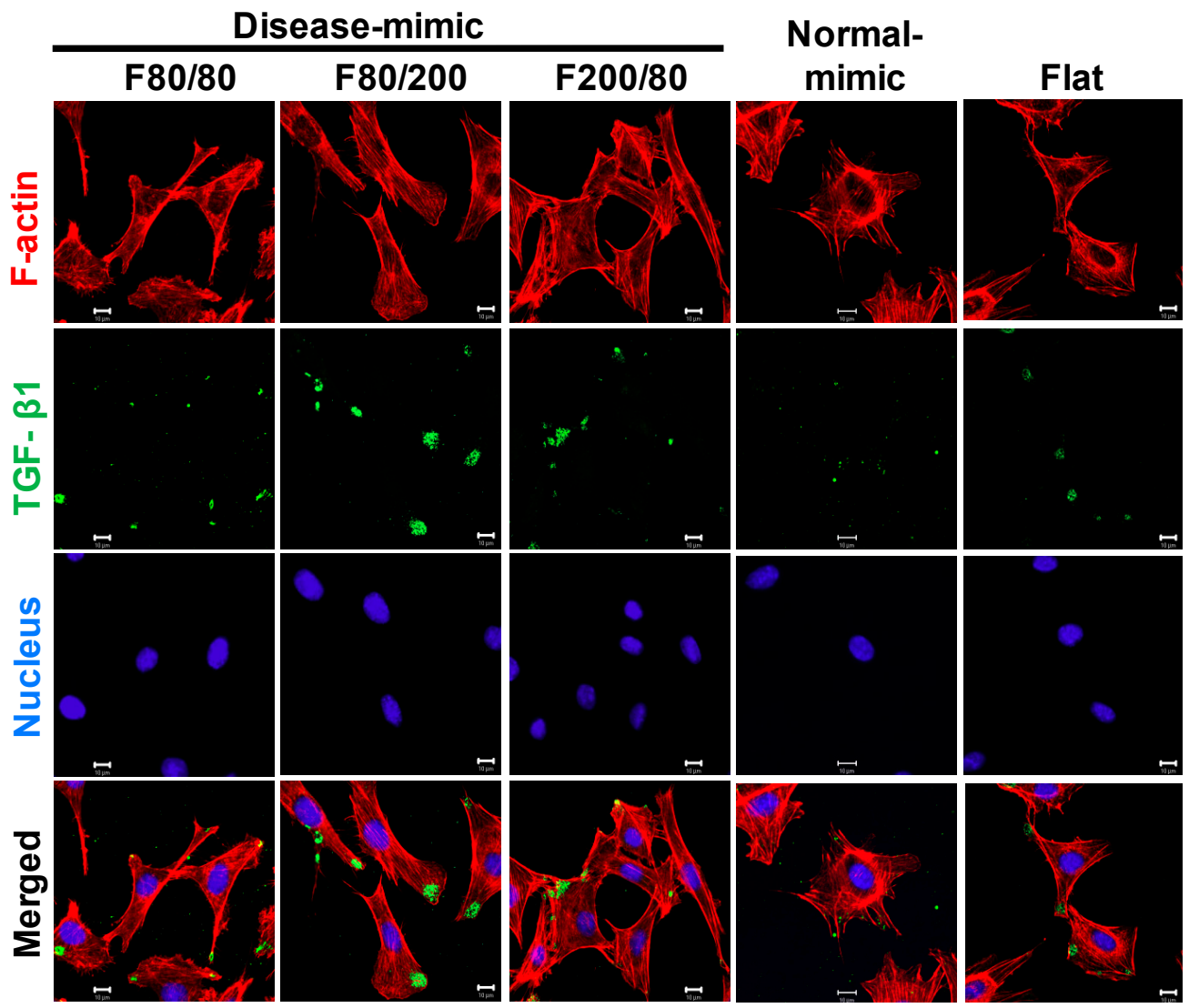

Figure 6. Transforming growth factor beta 1 (TGF- $\beta 1$ ) expression in MES13 cells influenced by diseaseand normal-mimic nanopatterns. Confocal microscopy images show TGF- $\beta 1$ (green), actin cytoskeleton (red), and nuclei (blue) in cells after culturing on $\mathrm{TiO}_{2}$ nanopatterns for $24 \mathrm{~h}$. Scale bar $=10 \mu \mathrm{m}$. 


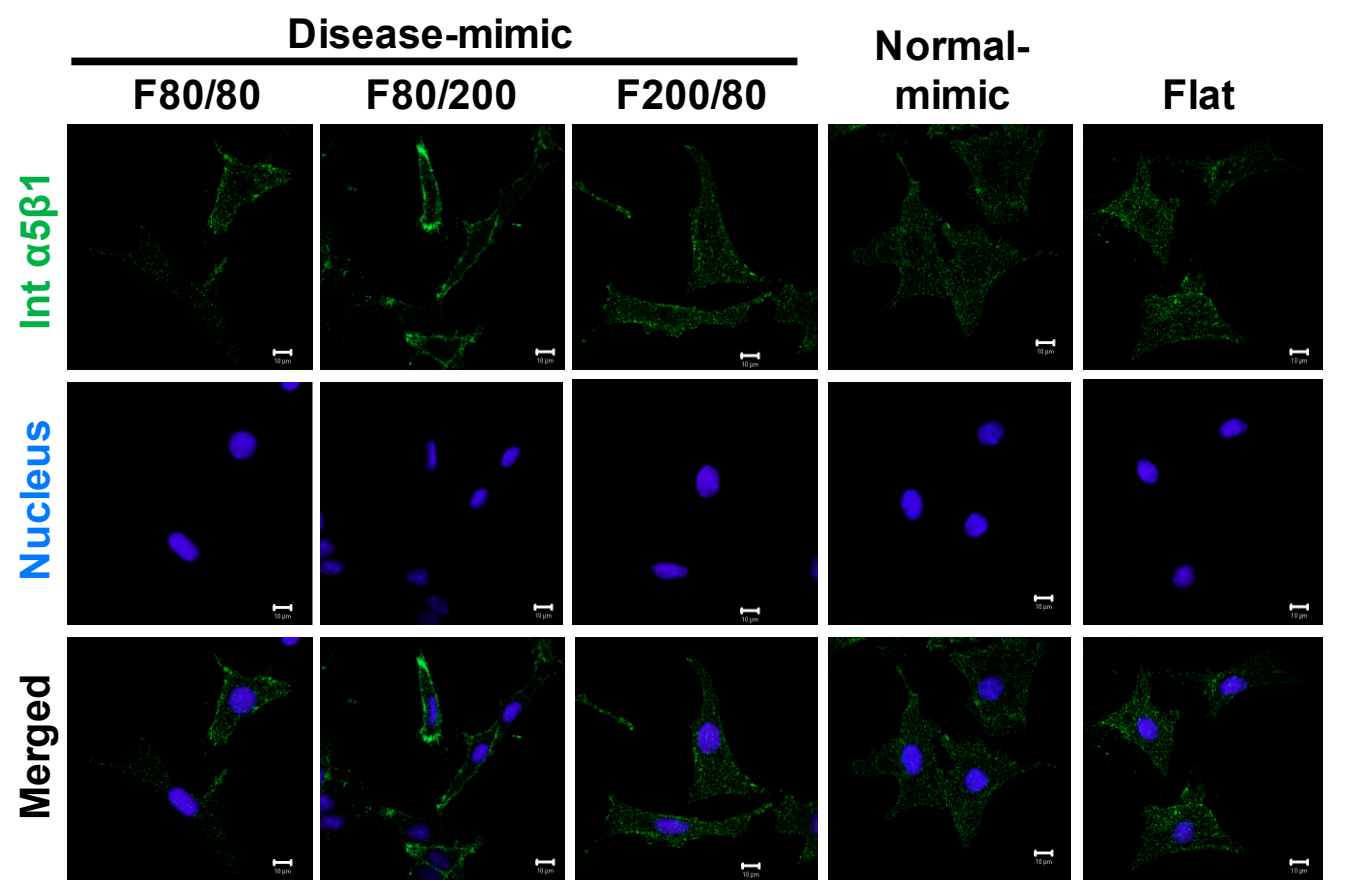

Figure 7. Integrin $\alpha 5 \beta 1$ expression in MES13 cells influenced by disease- and normal-mimic nanopatterns. Confocal microscopy images show integrin $\alpha 5 \beta 1$ (Int $\alpha 5 \beta 1$, green) and nuclei (blue) in cells after culturing on $\mathrm{TiO}_{2}$ nanopatterns for $24 \mathrm{~h}$. Scale bar $=10 \mu \mathrm{m}$.

\section{Discussion}

In this study, we investigated $\mathrm{TiO}_{2}$-based nanopatterns with specific sizes of topographic ridges and grooves that mimic the diseased native MM 3D structure that influences MES13 MC functions, including cell proliferation, ECM components and morphological changes.

To better mimic the in vivo native nanostructure, nano-fabrication techniques such as EBL can create the patterns at the nanoscale [26,27]. However, there are still some challenges with the throughput of electron beam projection systems, which are severely limited by the available optical field size, and can only pattern relatively small areas with a long writing time. Electron beam irradiation-induced defects also need to be considered. Thus, to overcome these challenges, approximately $80 \mathrm{~nm}$ was the minimum dimension used in our study to closely mimic the native collagen scaffold of MM. In this study, we fabricated highly uniform and well-defined nanostructures with 80 to $200 \mathrm{~nm}$ lateral dimensions and various geometries without obvious defects. A substrate with dimensions smaller than $80 \mathrm{~nm}$ is difficult to achieve due to the EBL and ALD limitations.

We fabricated five different $\mathrm{TiO}_{2}$-based nanopatterns, disease-mimic nanopatterns $\mathrm{F} 80 / 80, \mathrm{~F} 80 / 200$ and F200/80, and a normal-mimic and unpatterned flat control, to test our hypothesis that disease-mimic nano-topographical features influence $\mathrm{MC}$ function by controlling cell morphology. We designed the nanopatterns with different ridges/grooves to mimic COL1 fiber-forming structures in diseased MM. We also created a normal-mimic nanopattern with pores $80 \mathrm{~nm}$ wide, $80 \mathrm{~nm}$ apart, $50 \mathrm{~nm}$ in diameter and $80 \mathrm{~nm}$ in depth to mimic the COL4 network-forming structure in normal MM. In mammals, the diameter of collagen fibers, bundles of closely packed collagen fibrils, depends on the tissue and stage of development [40]. It has been found that COL1 fibers are located in parallel with one another, and are about $77 \mathrm{~nm}$ in diameter in the $\mathrm{MM}$ of diabetic nephropathy patients [41,42]. Moreover, a previous clinical study indicated that a significantly loosened, enlarged meshwork structure is detected in nephropathy MM [42]. These reports are consistent with our finding that the disease-mimic nanopattern F80/200, which is $80 \mathrm{~nm}$ wide with enlarged spacing $(200 \mathrm{~nm})$, closely mimics the diseased MM structure. 
MC proliferation and ECM accumulation are the major features in a variety of glomerular diseases $[1,2,8,43]$. Our results showed that cultured MES13 cells grown on the F80/200 nanopattern had higher proliferation, decreased normal MM components (COL4 and laminin $\alpha 1$ ) and secreted excessive abnormal ECM components (COL1 and fibronectin). On the other hand, cells grown on the normal-mimic nanopattern exhibited normal MC functions, such as low proliferation, and produced normal MM components (Figures 2 and 3). In fact, COL1 is absent in glomeruli under normal conditions, and excessive COL1 deposition is usually found in the early stage of renal fibrosis [44]. In addition, the accumulation of COL1 and fibronectin in mesangium by proliferating MCs is the direct result of mesangial expansion in many in vivo models and types of glomerular disease [2,17,45-47]. Laminin $\alpha 1$ is an essential ECM component in MM and plays a critical role in mesangial homeostasis by regulating the MC population and MM deposition through TGF- $\beta /$ Smad signaling [14]. Downregulated laminin $\alpha 1$ in $M M$ has been shown to affect MC function and result in mesangium expansion [47]. Increased TGF- $\beta 1$-mediated fibronectin accumulation in MM is also involved in many renal diseases [48].

MM components can cause MC morphology alterations and differentiation, as well as affect the MC secretion of ECM [13]. MCs maintain the structural integrity of the glomerular microvascular to regulate blood flow by their contractile cytoskeleton, which is formed by F-actin-containing stress fibers [49]. F-actin forms FA protein complexes at stress fiber ends and co-localizes with the actin-binding protein vinculin [34]. In our results, MES13 cells grown on the F80/200 nanopattern showed elongated and fusiform morphologies with diffused vinculin, which was slightly different from those grown on other nanopatterns, indicating that the F80/200 nanopattern influenced MC activation, but had less effect on FA maturation [50]. Compared with the normal-mimic, F80/80 and F200/80 nanopatterns showed cells that were stellate in shape with abundant F-actin stress fibers with vinculin, suggesting that cells were more developed on these nanopatterned topographies than on the flat control. Our findings suggested that the disease-mimic nanopattern (F80/200) influence of cell proliferation and altered MM components might be related to the change in cell morphology.

Although the phenomenon of cellular responses to nano-topography has been known for decades $[27,51,52]$, the underlying mechanism remains poorly understood. To further clarify the possible mechanism of MES13 changes in cell behavior when cultured on various nano-topographies, we evaluated the expressions of three proteins, $\alpha$-SMA, TGF- $\beta 1$ and integrin $\alpha 5 \beta 1$. MCs express smooth muscle cell-type actin, $\alpha$-SMA, during proliferation and repair processes after severe injury. However, $\alpha$-SMA is absent in normal MCs [12,35]. $\alpha$-SMA is also known as a marker of MC myofibroblast activation and differentiation in glomerular disease, and is mediated by TGF- $\beta 1$, a key mediator in the progression of renal fibrosis $[36,53,54]$. Moreover, TGF- $\beta 1$ has been demonstrated to induce $\alpha$-SMA expression by upregulating the fibronectin receptor, integrin $\alpha 5 \beta 1$, in human MCs during renal fibrosis in vivo and in vitro $[39,55,56]$. Increased expression of TGF- $\beta 1$ by MCs has also been demonstrated when MCs are cultured on COL1 gels [23]. In this study, the F80/200 nanopattern induced higher $\alpha$-SMA, TGF- $\beta 1$, and integrin $\alpha 5 \beta 1$ expressions in MES13 cells, which is similar to MCs under disease status, revealing that increased COL1 and fibronectin might be modulated by TGF- $\beta 1$ produced by activated MCs.

MCs also act to regulate the glomerular filtration rate (GFR) by modulating the capillaries' surface area [1]. Injured MCs could trigger TGF- $\beta 1$ release, and this then results in ECM accumulation in mesangium and tubular damage, and finally contributes to renal insufficiency [57]. Although the declined estimated GFR is the indicator of renal disease severity, it is not a specific indicator of early-stage renal damage induced by some diseases, such as IBD and diabetes [3,58]. Therefore, the promising biomarkers of renal damage, including NGAL and angiopoietins-2, might be useful for early prediction of MCs abnormality, which might be beneficial for early preventative therapy.

As a limitation of this study, the exact molecular pathway correlating with inflammatory effect and ECM accumulation in disease-like MCs induced by the disease-mimic nanopattern, has not been identified yet. Based on several previous reports, the expressions of NGAL and angiopoietins- 2 in 
disease-like MCs might be regulated by TGF- $\beta 1$. However, we would need to conduct additional experiments to further validate this speculation.

Our results indicated that disease-mimic nano-topographies influence MES13 cell functions, including changes in cell proliferation and altered MM components. A disease-mimic nanopattern of $80 \mathrm{~nm}$ depth, $80 \mathrm{~nm}$ wide and enlarged spacing (200 nm apart) guided cells to adopt diseased-like behaviors, including increased proliferation, excessive abnormal MM component production and decreased normal MM component production. Moreover, MES13 cells adopted elongated and fusiform morphologies with decreased FA maturation. These phenomena have been demonstrated in various in vitro glomerular disease models, and are positively correlated with $\alpha$-SMA and TGF- $\beta 1$ expressions. These findings may be important to further establish diseased models that mimic MM for elucidating the molecular mechanisms underlying glomerular disease, and also important for a drug screening platform.

\section{Materials and Methods}

\subsection{Fabrication of Nanopatterned $\mathrm{TiO}_{2}$ Substrates}

$\mathrm{TiO}_{2}$ substrates were fabricated as previously described [30,59]. Briefly, ZEP-520A positive-tone EBL resist (Nippon Zeon Co., Japan) was spin-coated on cleaned Si (100) substrates diluted in anisole (1:2 ratio) by a spin coater (Mikasa $1 \mathrm{H}-\mathrm{D} 7$ ) at $6000 \mathrm{rpm}$, and then baked at $180^{\circ} \mathrm{C}$ for $3 \mathrm{~min}$. Once the sample cooled to room temperature, a conductive material called Espacer (Showa Denko Co., Japan) was spin-coated at $2000 \mathrm{rpm}$ to obtain a very thin layer $(10-20 \mathrm{~nm})$. Next, the lithography patterns were written on the substrate with an EBL system (Elionix ELS-7500EX, acceleration voltage $=50 \mathrm{kV}$, ion beam amperage $=220 \mathrm{pA}$ ). The precise size of the fabricated substrate resulting from each e-beam was confirmed by SEM (FEG-SEM, Hitachi SU8230, Toronto ON, Canada). The exposed resist was then developed using $\mathrm{H} 2 \mathrm{O}$, n-amyl acetate and methyl isobutyl ketone (89\%)/isopropyl alcohol (11\%) (Wako Co., Japan) and dried by nitrogen gas. The substrates were then etched by inductively coupled plasma-reactive ion etching at $50 \mathrm{~W}$ (sulfur hexafluoride $2.5 \mathrm{cc} \mathrm{s}^{-1}+$ methyl tetrafluoride $3.5 \mathrm{cc} \mathrm{s}^{-1}$ ) with a total pressure of $0.1 \mathrm{~Pa}$ for $101 \mathrm{~s}$, followed by removing the resistance using $\mathrm{O}_{2}$ plasma, dimethyl acetamide and SPM solution $\left(\mathrm{H}_{2} \mathrm{SO}_{4}+\mathrm{H}_{2} \mathrm{O}_{2}, 3: 1\right)$, respectively. The substrates were then coated with a photoresist (AZ-5214E, Germany), subjected to UV irradiation with a photomask, reversal baking at $120{ }^{\circ} \mathrm{C}$, flood exposure to $\mathrm{UV}$, and development by hexamethyl disilazane and $2.38 \%$ tetramethyl ammonium hydroxide (Wako Co. Japan) for $1 \mathrm{~min}$, then rinsed with deionized water. Finally, the $\mathrm{TiO}_{2}$ thin films were deposited on Si substrates using atomic layer deposition (Picosun SUNALE R-150) with $500 \mathrm{~Pa}$ of the chamber pressure and at $100^{\circ} \mathrm{C}$. The thickness of the $\mathrm{TiO}_{2}$ layer was controlled by the number of cycles: 70 cycles gave a thickness of $5 \mathrm{~nm}$. The $\mathrm{TiO}_{2}$ precursor [tetra(dimethylamino)titanate] was pumped into the chamber, followed by argon gas to remove the undeposited precursor. $\mathrm{Next}_{2} \mathrm{H}_{2} \mathrm{O}$ vapor was pumped in to form the inorganic $\mathrm{TiO}_{2}$ layer from the organic precursor, and then argon gas was pumped in to remove residual $\mathrm{H}_{2} \mathrm{O}$. Fabricated $\mathrm{TiO}_{2}$ nanopattern surfaces were characterized by SEM (SU8230, Hitachi, Japan) and AFM (Ti950, Hysitron, MN, USA). Further experiments were performed using the fabricated substrates after dry heat sterilization of the substrate at $170{ }^{\circ} \mathrm{C}$ for $1 \mathrm{~h}$. A non-patterned flat surface was used as a control.

\subsection{Cell Culture}

A mouse immortalized mesangial cell line, SV40MES13 (MES13), was purchased from the American Type Culture Collection (Manassas, VA, USA). Cells were cultured in a 3:1 mixture of Dulbecco's modified Eagle's medium(DMEM)/Ham's F12 medium (Nacalai Tesque, Kyoto, Japan) with supplemented 5\% fetal bovine serum (FBS) (Corning Life Sciences, NY, USA), 14 mM HEPES (Gibco, MD, USA), and $100 \mathrm{U} / \mathrm{mL}$ penicillin/streptomycin (Nacalai Tesque). Cells were incubated in a humidified incubator at $37^{\circ} \mathrm{C}$ with $5 \% \mathrm{CO}_{2}$. All experiments were performed between passages 8 and 
9 to minimize the effects of phenotypic variation in continuous culture. Cells were serum-starved with $1 \% \mathrm{FBS}$ for $24 \mathrm{~h}$ or $48 \mathrm{~h}$ prior to examination.

\subsection{Cell Proliferation Assays}

The proliferation of cells grown on the nanopattern was evaluated by EdU incorporation using an EdU proliferation kit (iFluor 488) (Abcam, Cambridge, UK) and detected according to the manufacturer's instructions. Briefly, cells were seeded on various $\mathrm{TiO}_{2}$ nanopatterns or flat substrate at a concentration of $4 \times 10^{4}$ cells/well with serum-starved medium (1\% FBS) for $24 \mathrm{~h}$ in 24 -well plates, then incubated with $10 \mu \mathrm{M}$ EdU solution for $2 \mathrm{~h}$ at $37{ }^{\circ} \mathrm{C}$ in $5 \% \mathrm{CO}_{2}$. Subsequently, the cells were fixed with $4 \%$ formaldehyde for $15 \mathrm{~min}$. After rinsing with $3 \% \mathrm{BSA}$ in phosphate buffered saline (PBS, pH 7.4, Sigma-Aldrich, St. Louis, MO, USA), cells were permeated with $0.5 \%$ Triton X-100 in PBS, incubated with iFluor 488 azide, and stained with $300 \mathrm{nM}$ 4',6-diamidino-2-phenylindole (DAPI, Abcam) for $30 \mathrm{~min}$. All images were acquired with a Zeiss LSM 510 META confocal microscope system (Carl Zeiss, Jena, Germany). At least 400 nuclei were counted per experiment.

\subsection{Immunofluorescence Staining and Confocal Imaging}

Immunofluorescence staining was performed using a previously described method [2]. Briefly, cells were grown on $\mathrm{TiO}_{2}$ nanopatterns for 24 or $48 \mathrm{~h}$, then washed three times with PBS. Cells were fixed in $4 \%$ formaldehyde at room temperature for $20 \mathrm{~min}$, permeabilized by $0.05 \%$ saponin (Sigma-Aldrich) in Tris-buffered saline (TBS, $50 \mathrm{mM}$ Trizma, $150 \mathrm{mM} \mathrm{NaCl}$, pH 7.6) for $15 \mathrm{~min}$, then blocked by $3 \%$ BSA (Sigma, USA) in TBS for $1 \mathrm{~h}$ at room temperature. Then cells were sequentially incubated with primary antibodies against COL1, COL4, $\alpha$-SMA (Abcam), fibronectin, laminin $\alpha 1$ (Santa Cruz Biotechnology, Santa Cruz, CA, USA), vinculin (Sigma-Aldrich), and TGF- $\beta 1$ (R\&D Systems, Minneapolis, MN, USA), respectively, at $4{ }^{\circ} \mathrm{C}$ overnight followed by incubation with secondary antibodies conjugated to Alexa Fluor ${ }^{\circledR} 488$ or 594 (Invitrogen, Carlsbad, CA, USA). Nuclei were stained with DAPI and double-stained with rhodamine-conjugated phalloidin (Life Technologies, Gaithersburg, MD, USA) for F-actin filaments. All images were acquired with a Zeiss LSM 510 META confocal microscope system.

\subsection{SEM for Cell Morphology}

SEM images (SU8230) were used to investigate cellular morphology by following the method described previously [48]. After being grown on $\mathrm{TiO}_{2}$ nanopatterns for $24 \mathrm{~h}$, the cells were washed three times with PBS, fixed with $2.5 \%$ glutaraldehyde (Wako, Osaka, Japan) at $4{ }^{\circ} \mathrm{C}$ for $2 \mathrm{~h}$, followed by post-fixation in 1\% osmium tetroxide in PBS for at least $24 \mathrm{~h}$, and then dehydrated in gradient concentrations of ethanol ( $50 \%$ to $100 \%$ ) for $10 \mathrm{~min}$. Finally, cells were dried with hexamethyldisilazane and air-dried before observation by SEM.

\subsection{Statistical Analysis}

Statistical analyses were performed using Prism 8 software (GraphPad, CA, USA). All data are expressed as means \pm standard error of the mean (SEM) from five replicates from each group in at least three independent experiments. The significance of differences between groups was analyzed using one-way Analysis of Variance (ANOVA) and Tukey's post hoc test for multiple comparisons. A probability level of $p<0.05$ was considered significant.

Author Contributions: C.-J.C. designed the study, acquired data, and drafted the manuscript. R.M. assisted immunostaining experiment. C.-J.C. and A.T. analyzed and interpreted data. A.T. and C.-J.C. provided critical revision. C.-J.C., A.T. and T.S. discussed the results and contributed to the final manuscript. A.T. carried out final approval of the version to be published.

Funding: This research was funded by NIMS project (PA304).

Acknowledgments: We thank Akihiko Ohi and Tomoko Ohki for their valuable technical advice and assistance. 
Conflicts of Interest: The authors declare that they have no conflict of interest, financial or otherwise, regarding this article.

$\begin{array}{ll}\text { Abbreviations } \\ \mathrm{MM} & \text { Mesangial matrix } \\ \mathrm{COL} 4 & \text { Type IV collagen } \\ \mathrm{COL} 1 & \text { Type I collagen } \\ \mathrm{MCs} & \text { Mesangial cells } \\ \alpha-\mathrm{SMA} & \text { Alpha-smooth muscle actin } \\ \mathrm{TGF}-\beta 1 & \text { Transforming growth factor } \beta 1 \\ \mathrm{ECM} & \text { Extracellular matrix } \\ \mathrm{EBL} & \text { Electron beam lithography } \\ \mathrm{TiO} & \text { Titanium dioxide } \\ \mathrm{ALD} & \text { Atomic layer deposition } \\ \mathrm{SEM} & \text { Scanning electron microscopy } \\ \mathrm{AFM} & \text { Atomic force microscopy } \\ \mathrm{MES13} & \text { Immortalized mesangial cell line, SV40MES13 } \\ \mathrm{NGAL} & \text { Neutrophil gelatinase-associated lipocalin }\end{array}$

\section{References}

1. Scindia, Y.M.; Deshmukh, U.S.; Bagavant, H. Mesangial pathology in glomerular disease: Targets for therapeutic intervention. Adv. Drug Deliv. Rev. 2010, 62, 1337-1343. [CrossRef] [PubMed]

2. Chang, C.J.; Wang, P.C.; Huang, T.C.; Taniguchi, A. Change in Renal Glomerular Collagens and Glomerular Filtration Barrier-Related Proteins in a Dextran Sulfate Sodium-Induced Colitis Mouse Model. Int. J. Mol. Sci. 2019, 20, 1458. [CrossRef] [PubMed]

3. Zylka, A.; Dumnicka, P.; Kusnierz-Cabala, B.; Gala-Bladzinska, A.; Ceranowicz, P.; Kucharz, J.; Zabek-Adamska, A.; Maziarz, B.; Drozdz, R.; Kuzniewski, M. Markers of Glomerular and Tubular Damage in the Early Stage of Kidney Disease in Type 2 Diabetic Patients. Mediat. Inflamm. 2018, 2018, 7659243. [CrossRef] [PubMed]

4. Sporek, M.; Dumnicka, P.; Gala-Bladzinska, A.; Ceranowicz, P.; Warzecha, Z.; Dembinski, A.; Stepien, E.; Walocha, J.; Drozdz, R.; Kuzniewski, M.; et al. Angiopoietin-2 Is an Early Indicator of Acute Pancreatic-Renal Syndrome in Patients with Acute Pancreatitis. Mediat. Inflamm. 2016, 2016, 5780903. [CrossRef] [PubMed]

5. Sporek, M.; Gala-Bladzinska, A.; Dumnicka, P.; Mazur-Laskowska, M.; Kielczewski, S.; Walocha, J.; Ceranowicz, P.; Kuzniewski, M.; Mitus, J.; Kusnierz-Cabala, B. Urine NGAL is useful in the clinical evaluation of renal function in the early course of acute pancreatitis. Folia. Med. Cracov. 2016, 56, $13-25$.

6. Zylka, A.; Gala-Bladzinska, A.; Dumnicka, P.; Ceranowicz, P.; Kuzniewski, M.; Gil, K.; Olszanecki, R.; Kusnierz-Cabala, B. Is Urinary NGAL Determination Useful for Monitoring Kidney Function and Assessment of Cardiovascular Disease? A 12-Month Observation of Patients with Type 2 Diabetes. Dis. Markers 2016, 2016, 8489543. [CrossRef] [PubMed]

7. Giehl, K.; Graness, A.; Goppelt-Struebe, M. The small GTPase Rac-1 is a regulator of mesangial cell morphology and thrombospondin-1 expression. Am. J. Physiol. Ren. Physiol 2008, 294, F407-F413. [CrossRef]

8. Schlondorff, D.; Banas, B. The mesangial cell revisited: No cell is an island. J. Am. Soc. Nephrol. 2009, 20, 1179-1187. [CrossRef]

9. Guo, L.; Luo, S.; Du, Z.; Zhou, M.; Li, P.; Fu, Y.; Sun, X.; Huang, Y.; Zhang, Z. Targeted delivery of celastrol to mesangial cells is effective against mesangioproliferative glomerulonephritis. Nat. Commun. 2017, 8, 878. [CrossRef]

10. Davies, M. The mesangial cell: A tissue culture view. Kidney Int. 1994, 45, 320-327. [CrossRef]

11. Kashgarian, M.; Sterzel, R.B. The pathobiology of the mesangium. Kidney Int. 1992, 41, 524-529. [CrossRef] [PubMed]

12. Dubus, I.; L'Azou, B.; Gordien, M.; Delmas, Y.; Labouyrie, J.P.; Bonnet, J.; Combe, C. Cytoskeletal reorganization by mycophenolic acid alters mesangial cell migration and contractility. Hypertension 2003, 42, 956-961. [CrossRef] [PubMed] 
13. Schena, F.P.; Gesualdo, L.; Grandaliano, G.; Montinaro, V. Progression of renal damage in human glomerulonephritides: Is there sleight of hand in winning the game? Kidney Int. 1997, 52, 1439-1457. [CrossRef] [PubMed]

14. Kurihara, H.; Sakai, T. Cell biology of mesangial cells: The third cell that maintains the glomerular capillary. Anat. Sci. Int. 2017, 92, 173-186. [CrossRef] [PubMed]

15. Kitamura, M.; Mitarai, T.; Maruyama, N.; Nagasawa, R.; Yoshida, H.; Sakai, O. Mesangial cell behavior in a three-dimensional extracellular matrix. Kidney Int. 1991, 40, 653-661. [CrossRef]

16. Alexakis, C.; Maxwell, P.; Bou-Gharios, G. Organ-specific collagen expression: Implications for renal disease. Nephron Exp. Nephrol. 2006, 102, e71-e75. [CrossRef]

17. Glick, A.D.; Jacobson, H.R.; Haralson, M.A. Mesangial deposition of type I collagen in human glomerulosclerosis. Hum. Pathol. 1992, 23, 1373-1379. [CrossRef]

18. Ortega-Velazquez, R.; Gonzalez-Rubio, M.; Ruiz-Torres, M.P.; Diez-Marques, M.L.; Iglesias, M.C.; Rodriguez-Puyol, M.; Rodriguez-Puyol, D. Collagen I upregulates extracellular matrix gene expression and secretion of TGF-beta 1 by cultured human mesangial cells. Am. J. Physiol. Cell Physiol 2004, 286, C1335-C1343. [CrossRef]

19. Ruef, C.; Kashgarian, M.; Coleman, D.L. Mesangial cell-matrix interactions. Effects on mesangial cell growth and cytokine secretion. Am. J. Pathol. 1992, 141, 429-439.

20. Knupp, C.; Squire, J.M. Molecular packing in network-forming collagens. Adv. Protein Chem. 2005, 70, 375-403.

21. Yang, Y.; Wang, K.; Gu, X.; Leong, K.W. Biophysical Regulation of Cell Behavior-Cross Talk between Substrate Stiffness and Nanotopography. Eng. (Beijing) 2017, 3, 36-54. [CrossRef] [PubMed]

22. Kim, D.H.; Provenzano, P.P.; Smith, C.L.; Levchenko, A. Matrix nanotopography as a regulator of cell function. J. Cell Biol. 2012, 197, 351-360. [CrossRef] [PubMed]

23. Dong, J.; Wei, H.; Han, M.; Guan, Y.; Wu, Y.; Li, H. Collagen type III glomerulopathy: A case report and review of 20 cases. Exp. Med. 2015, 10, 1445-1449. [CrossRef] [PubMed]

24. Hironaka, K.; Makino, H.; Yamasaki, Y.; Ota, Z. Renal basement membranes by ultrahigh resolution scanning electron microscopy. Kidney Int. 1993, 43, 334-345. [CrossRef]

25. Erisken, C.; Zhang, X.; Moffat, K.L.; Levine, W.N.; Lu, H.H. Scaffold fiber diameter regulates human tendon fibroblast growth and differentiation. Tissue Eng. Part. A 2013, 19, 519-528. [CrossRef]

26. Bae, H.; Chu, H.; Edalat, F.; Cha, J.M.; Sant, S.; Kashyap, A.; Ahari, A.F.; Kwon, C.H.; Nichol, J.W.; Manoucheri, S.; et al. Development of functional biomaterials with micro- and nanoscale technologies for tissue engineering and drug delivery applications. J. Tissue Eng. Regen Med. 2014, 8, 1-14. [CrossRef]

27. Ermis, M.; Antmen, E.; Hasirci, V. Micro and Nanofabrication methods to control cell-substrate interactions and cell behavior: A review from the tissue engineering perspective. Bioact Mater. 2018, 3, 355-369. [CrossRef]

28. von der Mark, K.; Park, J.; Bauer, S.; Schmuki, P. Nanoscale engineering of biomimetic surfaces: Cues from the extracellular matrix. Cell Tissue Res. 2010, 339, 131-153. [CrossRef]

29. Ozguldez, H.O.; Cha, J.; Hong, Y.; Koh, I.; Kim, P. Nanoengineered, cell-derived extracellular matrix influences ECM-related gene expression of mesenchymal stem cells. Biomater Res. 2018, 22, 32. [CrossRef]

30. Abdellatef, S.A.; Ohi, A.; Nabatame, T.; Taniguchi, A. Induction of hepatocyte functional protein expression by submicron/nano-patterning substrates to mimic in vivo structures. Biomater. Sci. 2014, 2, 330-338. [CrossRef]

31. Kim, D.; Li, H.Y.; Lee, J.H.; Oh, Y.S.; Jun, H.S. Lysophosphatidic acid increases mesangial cell proliferation in models of diabetic nephropathy via Rac1/MAPK/KLF5 signaling. Exp. Mol. Med. 2019, 51, 18. [CrossRef] [PubMed]

32. Ishimura, E.; Sterzel, R.B.; Morii, H.; Kashgarian, M. Extracellular matrix protein: Gene expression and synthesis in cultured rat mesangial cells. Nihon Jinzo Gakkai Shi 1992, 34, 9-17. [PubMed]

33. Bussolati, B.; Mariano, F.; Biancone, L.; Foa, R.; David, S.; Cambi, V.; Camussi, G. Interleukin-12 is synthesized by mesangial cells and stimulates platelet-activating factor synthesis, cytoskeletal reorganization, and cell shape change. Am. J. Pathol. 1999, 154, 623-632. [CrossRef]

34. Thwaites, T.R.; Pedrosa, A.T.; Peacock, T.P.; Carabeo, R.A. Vinculin Interacts with the Chlamydia Effector TarP Via a Tripartite Vinculin Binding Domain to Mediate Actin Recruitment and Assembly at the Plasma Membrane. Front. Cell Infect. Microbiol. 2015, 5, 88. [CrossRef] [PubMed] 
35. Xie, X.; Xia, W.; Fei, X.; Xu, Q.; Yang, X.; Qiu, D.; Wang, M. Relaxin Inhibits High Glucose-Induced Matrix Accumulation in Human Mesangial Cells by Interfering with TGF-beta1 Production and Mesangial Cells Phenotypic Transition. Biol. Pharm. Bull. 2015, 38, 1464-1469. [CrossRef]

36. Iwano, M.; Akai, Y.; Fujii, Y.; Dohi, Y.; Matsumura, N.; Dohi, K. Intraglomerular expression of transforming growth factor-beta 1 (TGF-beta 1) mRNA in patients with glomerulonephritis: Quantitative analysis by competitive polymerase chain reaction. Clin. Exp. Immunol. 1994, 97, 309-314. [CrossRef]

37. O'Connor, J.W.; Mistry, K.; Detweiler, D.; Wang, C.; Gomez, E.W. Cell-cell contact and matrix adhesion promote alphaSMA expression during TGFbeta1-induced epithelial-myofibroblast transition via Notch and MRTF-A. Sci. Rep. 2016, 6, 26226. [CrossRef]

38. Stephenson, L.A.; Haney, L.B.; Hussaini, I.M.; Karns, L.R.; Glass, W.F., 2nd. Regulation of smooth muscle alpha-actin expression and hypertrophy in cultured mesangial cells. Kidney Int. 1998, 54, 1175-1187. [CrossRef]

39. Adler, S.; Brady, H.R. Cell adhesion molecules and the glomerulopathies. Am. J. Med. 1999, 107, 371-386. [CrossRef]

40. Canty, E.G.; Starborg, T.; Lu, Y.; Humphries, S.M.; Holmes, D.F.; Meadows, R.S.; Huffman, A.; O'Toole, E.T.; Kadler, K.E. Actin filaments are required for fibripositor-mediated collagen fibril alignment in tendon. J. Biol. Chem. 2006, 281, 38592-38598. [CrossRef]

41. Makino, H.; Shikata, K.; Hironaka, K.; Kushiro, M.; Yamasaki, Y.; Sugimoto, H.; Ota, Z.; Araki, N.; Horiuchi, S. Ultrastructure of nonenzymatically glycated mesangial matrix in diabetic nephropathy. Kidney Int. 1995, 48, 517-526. [CrossRef] [PubMed]

42. Herrera, G.A.; Turbat-Herrera, E.A. Renal diseases with organized deposits: An algorithmic approach to classification and clinicopathologic diagnosis. Arch. Pathol Lab. Med. 2010, 134, 512-531. [PubMed]

43. Cove-Smith, A.; Hendry, B.M. The regulation of mesangial cell proliferation. Nephron Exp. Nephrol. 2008, 108, e74-e79. [CrossRef] [PubMed]

44. Genovese, F.; Manresa, A.A.; Leeming, D.J.; Karsdal, M.A.; Boor, P. The extracellular matrix in the kidney: A source of novel non-invasive biomarkers of kidney fibrosis? Fibrogenesis Tissue Repair 2014, 7, 4. [CrossRef]

45. Hubchak, S.C.; Sparks, E.E.; Hayashida, T.; Schnaper, H.W. Rac1 promotes TGF-beta-stimulated mesangial cell type I collagen expression through a PI3K/Akt-dependent mechanism. Am. J. Physiol Ren. Physiol. 2009, 297, F1316-F1323. [CrossRef]

46. Brodeur, A.C.; Roberts-Pilgrim, A.M.; Thompson, K.L.; Franklin, C.L.; Phillips, C.L. Transforming growth factor-beta1/Smad3-independent epithelial-mesenchymal transition in type I collagen glomerulopathy. Int J. Nephrol Renov. Dis. 2017, 10, 251-259. [CrossRef]

47. Ning, L.; Kurihara, H.; de Vega, S.; Ichikawa-Tomikawa, N.; Xu, Z.; Nonaka, R.; Kazuno, S.; Yamada, Y.; Miner, J.H.; Arikawa-Hirasawa, E. Laminin alpha1 regulates age-related mesangial cell proliferation and mesangial matrix accumulation through the TGF-beta pathway. Am. J. Pathol. 2014, 184, 1683-1694. [CrossRef]

48. Hu, C.; Sun, L.; Xiao, L.; Han, Y.; Fu, X.; Xiong, X.; Xu, X.; Liu, Y.; Yang, S.; Liu, F.; et al. Insights into the Mechanisms Involved in the Expression and Regulation of Extracellular Matrix Proteins in Diabetic Nephropathy. Curr. Med. Chem. 2015, 22, 2858-2870. [CrossRef]

49. Cortes, P.; Mendez, M.; Riser, B.L.; Guerin, C.J.; Rodriguez-Barbero, A.; Hassett, C.; Yee, J. F-actin fiber distribution in glomerular cells: Structural and functional implications. Kidney Int. 2000, 58, 2452-2461. [CrossRef]

50. Lutz, R.; Pataky, K.; Gadhari, N.; Marelli, M.; Brugger, J.; Chiquet, M. Nano-stenciled RGD-gold patterns that inhibit focal contact maturation induce lamellipodia formation in fibroblasts. PLoS ONE 2011, 6, e25459. [CrossRef]

51. Wang, K.; Bruce, A.; Mezan, R.; Kadiyala, A.; Wang, L.; Dawson, J.; Rojanasakul, Y.; Yang, Y. Nanotopographical Modulation of Cell Function through Nuclear Deformation. Acs Appl Mater. Interfaces 2016, 8, 5082-5092. [CrossRef] [PubMed]

52. Abdellatef, S.A.; Tange, R.; Sato, T.; Ohi, A.; Nabatame, T.; Taniguchi, A. Nanostructures Control the Hepatocellular Responses to a Cytotoxic Agent “Cisplatin". Biomed. Res. Int 2015, 2015, 925319. [CrossRef] [PubMed] 
53. Hewitson, T.D.; Holt, S.G.; Tan, S.J.; Wigg, B.; Samuel, C.S.; Smith, E.R. Epigenetic Modifications to H3K9 in Renal Tubulointerstitial Cells after Unilateral Ureteric Obstruction and TGF-beta1 Stimulation. Front. Pharm. 2017, 8, 307. [CrossRef] [PubMed]

54. Meran, S.; Steadman, R. Fibroblasts and myofibroblasts in renal fibrosis. Int. J. Exp. Pathol. 2011, 92, $158-167$. [CrossRef] [PubMed]

55. Huang, G.; Brigstock, D.R. Integrin expression and function in the response of primary culture hepatic stellate cells to connective tissue growth factor (CCN2). J. Cell Mol. Med. 2011, 15, 1087-1095. [CrossRef]

56. Weston, B.S.; Wahab, N.A.; Mason, R.M. CTGF mediates TGF-beta-induced fibronectin matrix deposition by upregulating active alpha5beta1 integrin in human mesangial cells. J. Am. Soc. Nephrol 2003, 14, 601-610. [CrossRef]

57. Ghayur, M.N.; Krepinsky, J.C.; Janssen, L.J. Contractility of the Renal Glomerulus and Mesangial Cells: Lingering Doubts and Strategies for the Future. Med. Hypotheses Res. 2008, 4, 1-9.

58. Oikonomou, K.; Kapsoritakis, A.; Eleftheriadis, T.; Stefanidis, I.; Potamianos, S. Renal manifestations and complications of inflammatory bowel disease. Inflamm. Bowel Dis. 2011, 17, 1034-1045. [CrossRef]

59. Abdellatef, S.A.; Ohi, A.; Nabatame, T.; Taniguchi, A. The Effect of Physical and Chemical Cues on Hepatocellular Function and Morphology. Int. J. Mol. Sci. 2014, 15, 4299-4317. [CrossRef]

(C) 2019 by the authors. Licensee MDPI, Basel, Switzerland. This article is an open access article distributed under the terms and conditions of the Creative Commons Attribution (CC BY) license (http://creativecommons.org/licenses/by/4.0/). 